\title{
Editorial
}

\section{To Live Until We Say Goodbye}

\author{
Bruce Kaye
}

In 1969 Elisabeth Kubler-Ross published a ground-breaking book, On Death and Dying, in which she outlined the stages that people go through as they let go of their living connections. The 'five psychological stages of dying' (denial, anger, bargaining, depression and finally acceptance) that she outlined became an almost universal commonplace and provided the foundation for care of the dying in many countries around the world. She believed there was much that we could learn from the dying. 'At the end of your life, nobody asks you how many degrees you have, or how many mansions you built, or how many Rolls Royces you could afford. That's what dying patients teach you. ${ }^{\prime 1}$ It was this truth which led her to encourage people to live their present lives in the understanding that they do so until they say goodbye. It was a way of focusing on those things which are central and which we would regard as important in the light of our death. Kubler-Ross's insight has enriched and liberated the lives of countless numbers of people around the world.

It is a message which in its humanity is resonant with the Christian belief that we live in the light of eternity, that the Christian is called to live their life in the sure and certain expectation of the resurrection. The theme is replete in Jesus' words: 'No one knows about that day or hour, not even the angels in heaven, nor the Son, but only the Father. Be on guard! Be alert!' (Mk 13.32). In the Sermon on the Mount Jesus tells his listeners not to store up treasure on earth, but to store up treasures in heaven 'for where your treasure is there your heart will be also' (Mt. 6.21).

While death is the final transition we make, our lives are made up of all sorts of transitions along the way. We live out of the past into the future by making transitions in the present. The Christian pilgrimage is marked by processes of letting go and embracing.

Of course we never absolutely let go of the past. That is beyond our capacity. Our letting go and embracing is in fact a changing of the profile

1. Used with permission of the Elisabeth Kubler-Ross Foundation from the website at http:/ / www.elisabethkublerross.com/ 
of the continuity between the past, the present and the future in which we live. Many of these transitions come to us uninvited and we are caught up in simply responding in the best way we can in the light of our heritage, our faith and our hope. Some transitions come to us because of the normal process of maturing and ageing. Some are brought to us by the circumstances of life, even by the interactions of our friends.

These truths apply also to communities of people. Communities like Anglicans in parishes, dioceses or the worldwide communion of Anglican churches. In communities these transitions are often matters of contention, as is the case at the present time with Anglican churches around the world. The challenge we often face in such circumstances is to know what things we are to let go and which things to embrace. That is a struggle for insight and the fact of the struggle and its tendencies contribute to the emerging shape of the community. However, the essential moral and Christian character of the community is also shaped and influenced by the way in which these struggles are conducted. To debate, argue, controvert in a manner which, in the piercing light of the Kingdom of Heaven, lacks compassion, humility or respect, hardly belongs in a community which is supposed to be defined by these gospel qualities of Christian faith. That way of arguing in fact undermines the essential virtues of the community.

This issue of the Journal of Anglican Studies points to some very important challenges which are part of our current Anglican community worldwide. The nature of the Anglican Communion and the formative role it plays in the life of local communities are present in the article by Carlos Calvani. We are especially glad to welcome our first contribution from Latin America. It is a voice from the edge of the usual noise of international debate and it brings fresh challenges and questions. Ian Douglas speaks out of a missiologist's concerns about the Windsor Report in tones which offer a model of grace in controversy. His reflection is a major review of the Windsor Report and lays out very clearly issues which will need to be addressed in any 'reception'. A 'reception' process is undoubtedly a good thing to have in place to follow up the publication of the Windsor Report. It is to be hoped that it will enable some accurate assessment to be made available of the response to the report around the Communion. This will be a great advance over the fate of one of its predecessors, the Virginia Report, a report which seems to have more life in subsequent reports than anywhere else.

Tom Wright and Mark Chapman remind us of two figures of controversy from the past; Charles Gore and John Robinson. Looking back on past transitions, or putative transitions, provides an opportunity to learn how to respond to current offerings. John Robinson's book Honest to God 
was a whirlwind best seller, but it is quite unclear what enduring transition it either reflected or encouraged. Testing its proposals at a distance offers an opportunity for a reflexive consideration of the present. The same is true of Mark Chapman's presentation on Charles Gore.

Much of the debate about sexuality sits within a context of relations with Islam. The series of conversations between Anglicans and Muslims that have been developed in recent years is a vital backdrop for Anglicans to the wider encounter of the great religions which is so much a mark of contemporary geopolitics. John Ipgrave's closely informed contribution brings us to the heart of these conversations.

The Journal of Anglican Studies came into existence to encourage scholarly conversation among Anglicans around the world. The Archbishop of Canterbury has initiated the work of a commission on Theological Education in the Anglican Communion (TEAC). The Journal of Anglican Studies supports this project and trusts that it will prosper. It is vital to our mutual understanding that our theologians around the world not only understand each other, but also constitute a guild of service to the churches of the Communion. We need our theologians flourishing and working together as never before. It is therefore a very great pleasure to have Rowan Williams return to the pages of the Journal of Anglican Studies with the Conversation piece in this issue. 